Paladini G, Gustinelli A, Fioravanti ML, Hansen H \& Shinn A (2009) The first report of Gyrodactylus salaris Malmberg, 1957 (Platyhelminthes, Monogenea) on Italian cultured stocks of rainbow trout (Oncorhynchus mykiss Walbaum), Veterinary Parasitology, 165 (3-4), pp. 290-297.

This is the peer reviewed version of this article

NOTICE: this is the author's version of a work that was accepted for publication in Veterinary Parasitology. Changes resulting from the publishing process, such as peer review, editing, corrections, structural formatting, and other quality control mechanisms may not be reflected in this document. Changes may have been made to this work since it was submitted for publication. A definitive version was subsequently published in Veterinary Parasitology, [VOL 165, ISSUE 3-4, (2009)] DOI 10.1016/j.vetpar.2009.07.025 
Provided for non-commercial research and education use. Not for reproduction, distribution or commercial use.

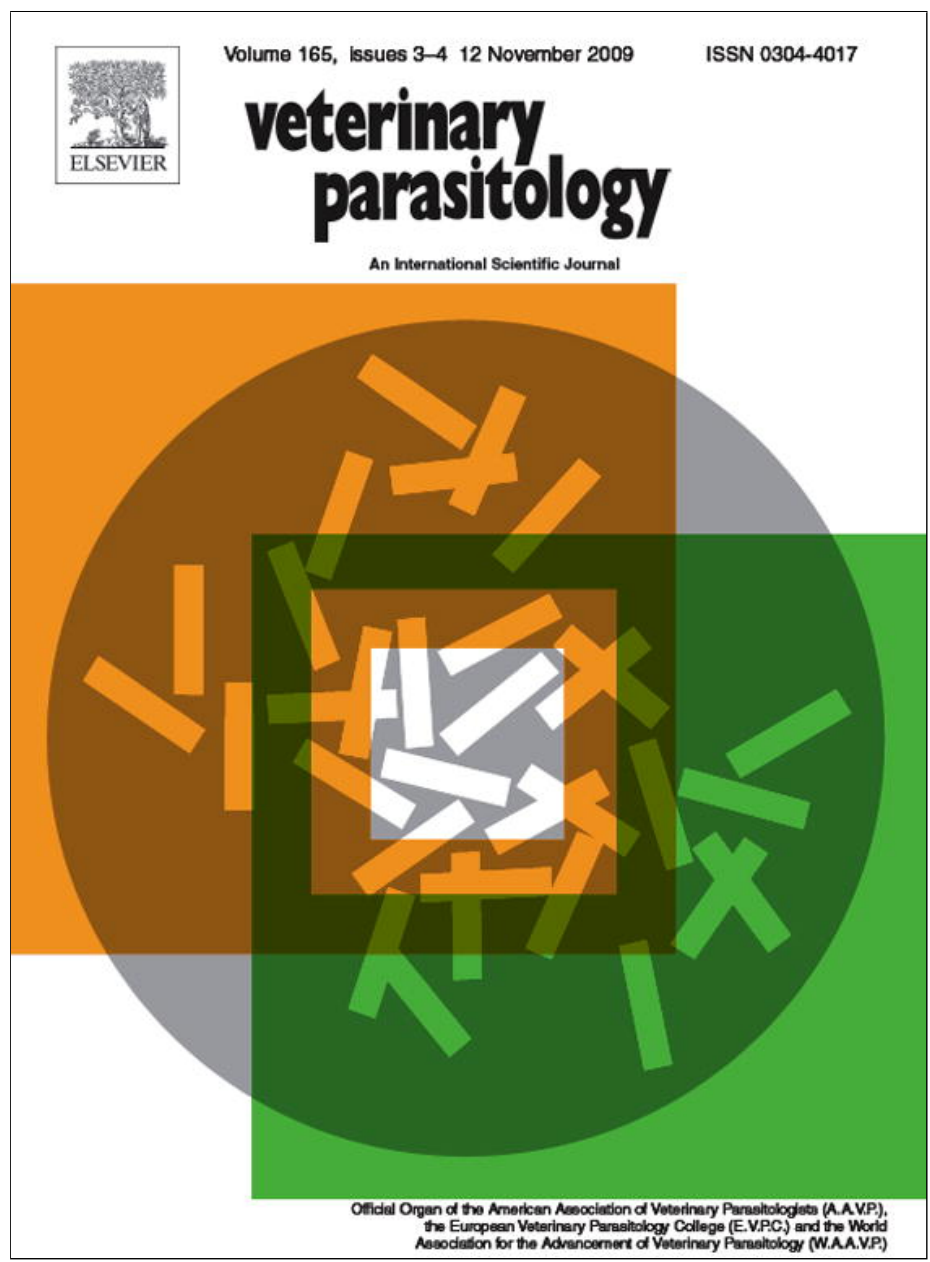

This article appeared in a journal published by Elsevier. The attached copy is furnished to the author for internal non-commercial research and education use, including for instruction at the authors institution and sharing with colleagues.

Other uses, including reproduction and distribution, or selling or licensing copies, or posting to personal, institutional or third party websites are prohibited.

In most cases authors are permitted to post their version of the article (e.g. in Word or Tex form) to their personal website or institutional repository. Authors requiring further information regarding Elsevier's archiving and manuscript policies are encouraged to visit:

http://www.elsevier.com/copyright 


\title{
The first report of Gyrodactylus salaris Malmberg, 1957 (Platyhelminthes, Monogenea) on Italian cultured stocks of rainbow trout (Oncorhynchus mykiss Walbaum)
}

\author{
Giuseppe Paladini a,c,* Andrea Gustinelli ${ }^{\text {a }}$, Maria L. Fioravanti ${ }^{\text {a }}$, \\ Haakon Hansen ${ }^{\mathrm{b}}$, Andrew P. Shinn ${ }^{\mathrm{c}}$ \\ a Department of Veterinary Public Health and Animal Pathology, University of Bologna, Via Tolara di Sopra, 50 - 40064 Ozzano dell'Emilia (BO), Italy \\ ${ }^{\mathrm{b}}$ National Veterinary Institute, Section for Parasitology, PO Box 750 Sentrum, N-0106 Oslo, Norway \\ ${ }^{\mathrm{c}}$ Institute of Aquaculture, University of Stirling, Stirling, Stirlingshire FK9 4LA, UK
}

\section{A R T I C L E I N F O}

Article history:

Received 27 January 2009

Received in revised form 13 July 2009

Accepted 15 July 2009

\section{Keywords:}

Gyrodactylus salaris

G. teuchis

G. derjavinoides

G. truttae

Rainbow trout

Oncorhynchus mykiss

Italy

\begin{abstract}
A B S T R A C T
The monogenean Gyrodactylus salaris Malmberg, 1957 is considered one of the most important parasites of wild salmonids in the European Community due to the heavy ecological and economical damage it has inflicted on Atlantic salmon (Salmo salar) parr populations. Rainbow trout (Oncorhynchus mykiss) is susceptible to G. salaris and can act as a suitable carrier host and, consequently, its trade in EU territory is restricted in relation to the status of "recognized free" zones. Despite the economic importance of rainbow trout farming in Italy, information on the Italian gyrodactylid fauna is lacking and prior to this study, G. salaris had not been officially reported. During a routine health examination of farmed rainbow trout stock throughout Central and Northern Italy in 2004-2005, five fish farms were found to be infected with $G$. salaris alongside three other gyrodactylids. Morphological and molecular characterisation confirmed the presence of G. salaris, Gyrodactylus teuchis Lautraite, Blanc, Thiery, Daniel et Vigneulle, 1999 and Gyrodactylus derjavinoides Malmberg, Collins, Cunningham et Jalali, 2007, while Gyrodactylus truttae Gläser, 1974 was identified by morphological analysis only. The findings from this study extend the distribution of $G$. salaris within Europe and highlight the importance of the rainbow trout trade in its dissemination.
\end{abstract}

(c) 2009 Elsevier B.V. All rights reserved.

\section{Introduction}

The importance of Gyrodactylus salaris Malmberg, 1957 is demonstrated by the heavy losses that this monogenean has caused over the last thirty years in parr and smolt stages of wild Atlantic salmon (Salmo salar L.), principally throughout Norway (Johnsen et al., 1999; Bakke et al., 2007). Apart from being a parasite of Atlantic salmon, $G$.

\footnotetext{
* Corresponding author at: Institute of Aquaculture, University of Stirling, Stirling, Stirlingshire FK9 4LA, UK. Tel.: +44 1786 473171; fax: +44 1786472133.

E-mail address: paladini2000@yahoo.it (G. Paladini).
}

salaris can colonise and reproduce on a wide number of salmonid species without clinical signs of disease and these hosts represent important carriers of the parasite (Bakke et al., 2002). In particular, rainbow trout (Oncorhynchus mykiss Walbaum) is considered as an ideal reservoir for $G$. salaris, being a very receptive and generally asymptomatic host (Bakke et al., 2002). For this reason, the movement of rainbow trout within the European Community is strictly regulated and is permitted only between regions of equivalent health status (Peeler et al., 2006).

Most species of Gyrodactylus can be differentiated by the morphological features of their haptoral hard parts (Malmberg, 1970) and/or by differences in their ribosomal internal transcribed spacer (ITS1 and ITS2) regions 
(Matejusová et al., 2001; Ziętara and Lumme, 2002). The discrimination of $G$. salaris from other related species is, however, not always straightforward. Gyrodactylus salaris and the purported non-pathogenic Gyrodactylus thymalli Žitňan, 1960 from grayling, Thymallus thymallus L., are morphologically similar, their ITS sequences are practically identical, and recent studies indicate that the two species might be conspecific (Ziętara and Lumme, 2002; Hansen et al., 2003, 2006, 2007; Meinilä et al., 2004). Analyses of the mitochondrial cytochrome oxidase I gene (COI), however, show that G. salaris and G. thymalli can be grouped in different clades and that all the gyrodactylids from rainbow trout appear to belong to the same COI haplotype (Hansen et al., 2003; Meinilä et al., 2004). Although characterisation by COI does not seem to be linked to the virulence of $G$. salaris (Hansen et al., 2007), its determination, however, does provide hints to its possible origin and relationship to other populations within the species. Similarly Gyrodactylus teuchis Lautraite, Blanc, Thiery, Daniel et Vigneulle, 1999 was first considered to be morphologically similar to $G$. salaris but it was later shown that it could be characterised as a separate species based on its ITS sequences (Lautraite et al., 1999; Cunningham et al., 2001).

Rainbow trout production in Italy represents a significant proportion of the nation's freshwater production with over 39,000 tons/year (API, 2008), but data on infection of Gyrodactylus spp. of farmed salmonids is scarce. With reference to G. salaris, Molnár and Ghittino (1977) reported a gyrodactylid from cultured rainbow trout and brown trout (Salmo trutta L.) from Italy but no further studies were carried out to confirm the identity of these or to define their distribution throughout the country. The current study, therefore, set out to establish the gyrodactylid fauna on captive held populations of rainbow trout in Northern and Central Italy.

\section{Materials and methods}

During the period March to May 2005, five Italian rainbow trout farms were visited throughout the Central and Northern regions of Italy and a sample of stock at each site was examined for the presence of Gyrodactylus spp. Ten fish, ranging in $10-40 \mathrm{~cm}$ total length, were sampled from each site. Fish were euthanased and a representative mucus sample was taken from the body and fins of each fish using a scalpel and then fixed immediately in 70\% ethanol for analysis in the laboratory. The fish farms situated on five different water systems were positive for Gyrodactylus: the River Sile, Veneto $\left(45^{\circ} 38^{\prime} 23.18^{\prime \prime} \mathrm{N}\right.$, $12^{\circ} 08^{\prime} 14.29^{\prime \prime} \mathrm{E}$ ), the Avisio Torrent, Trentino Alto Adige $\left(46^{\circ} 16^{\prime} 42.70^{\prime \prime} \mathrm{N}, 11^{\circ} 26^{\prime} 39.52^{\prime \prime} \mathrm{E}\right)$, the River Sérchio, Tuscany $\left(44^{\circ} 02^{\prime} 52.00^{\prime \prime} \mathrm{N}, 10^{\circ} 27^{\prime} 39.74^{\prime \prime} \mathrm{E}\right)$, and two sites in the Umbria region, the Clitunno Fountain $\left(42^{\circ} 44^{\prime} 41.95^{\prime \prime} \mathrm{N}\right.$, $\left.12^{\circ} 42^{\prime} 24.81^{\prime \prime} \mathrm{E}\right)$ and the River Nera $\left(42^{\circ} 51^{\prime} 41.38^{\prime \prime} \mathrm{N}\right.$, $12^{\circ} 58^{\prime} 48.84^{\prime \prime} \mathrm{E}$ ) (Fig. 1).

Gyrodactylid parasites were isolated from the fixed mucus and prepared for morphological and molecular analyses. Individual specimens were placed on a glass slide, the haptor was removed using a scalpel and subjected to proteolytic digestion using a modification of the method given in Harris and Cable (2000), i.e. $3 \mu \mathrm{l}$ of digestion solution (100 $\mu \mathrm{g} / \mathrm{ml}$ proteinase $\mathrm{K}$ (Cat \# 4031-1, Clontech UK Ltd., Basingstoke, UK), $75 \mathrm{mM}$ Tris-HCl (Sigma-Aldrich, Poole, UK), 10 mM EDTA (Sigma-Aldrich), 5\% SDS (Sigma-Aldrich)) added to each haptor. The digestion of each specimen was continuously monitored under a $4 \times$ objective on an Olympus SZ30 dissecting microscope. Tissue digestion was then arrested and mounted in situ by the addition of $2 \mu$ l of a $1: 1$ saturated ammonium picrate: $100 \%$ glycerine mix. The edges of the coverslip were then sealed with nail varnish.

The digested, ammonium picrate glycerine mounted specimens were photographed using a JVC KY-F30B 3CCD camera with an interfacing $2.5 \times$ top lens fitted to an Olympus $\mathrm{BH} 2$ compound fitted with phase contrast under a $100 \times$ oil immersion objective and features of the hooks measured using Zeiss $\mathrm{KS} 300 \mathrm{iC} /$ Windows release ver 3.0 (1997) (Carl Zeiss Vision GmbH, Munchen, Germany/ Imaging Associates Ltd., Thame, Oxfordshire, UK) software. For identification, a total of 25 point-to-point morphometrics (11 on the hamulus, 6 on the ventral bar and 8 on the marginal hooks) were made on each specimen (see Shinn et al., 2004) using the purpose written software PointR ver 1.0 ( $\odot$ Shinn and Bron, 2003, University of Stirling, UK) within KS300.

The excised body of each gyrodactylid was transferred to an individual, labelled $1.5 \mathrm{ml}$ Eppendorf tube and stored in $95 \%$ ethanol until required. A limited number of specimens from each of the sampled locations were available for molecular analysis. DNA was extracted from individually isolated specimens using the DNEasyKit or Mini Kit (Qiagen) following the manufacturer's instructions. The primer pairs ITS1A (5'-GTAACAAGGTTTCCGTAGGTG- $\left.3^{\prime}\right)$ and ITS2 (5'-TCCTCCGCTTAGTGATA- ${ }^{\prime}$ ) (Matejusová et al., 2001) were used to amplify a fragment spanning the $3^{\prime}$ end of the $18 \mathrm{~S}$ subunit, ITS1-5.8S-ITS2 and the $5^{\prime}$ end of the $28 \mathrm{~S}$ subunit. In instances where this full fragment did not amplify, the primers ITS4.5 and ITS2 (Matejusová et al., 2001) were used to amplify the ITS2 region separately. ITS2 alone contains less variation than ITS1, but nevertheless differs between all species studied herein.

The primer pairs ZMO1 (5'-GCGMCTAAATGCTTTAAGGGCTTG-3' ${ }^{\prime}$ and ZMO4 (5'-GAGGATAGCACTATCCCTGTCAC-3') (Hansen et al., 2003) were used to amplify the mitochondrial COI. All PCR reactions were performed with puRe Taq Ready-to-Go PCR beads (Amersham Biosciences) in a GeneAmp PCR System 9700 (Applied Biosystems) using the following protocol: $4 \mathrm{~min}$ at $95^{\circ} \mathrm{C}$, followed by 35 cycles of $1 \mathrm{~min}$ at $95^{\circ} \mathrm{C}, 1 \mathrm{~min}$ at $50{ }^{\circ} \mathrm{C}$ and 2 min at $72{ }^{\circ} \mathrm{C}$.

All PCR-products were purified using a QIAquick PCR Purification Kit (Qiagen) or Macherey-Nagel NucleoSpin ${ }^{\circledR}$ Extract II according to the manufacturer's recommendations. Both DNA strands were sequenced on a MEGABACE 1000 (GE Healthcare) using DyeET-terminator mix (GEHealthcare) and were carried out in $10 \mu$ l reactions. The PCR primers and the internal primers ITS1R (5'ATTTGCGTTCGAGAGACCG-3') and ITS2F (5'-TGGTGGATCACTCGGCTCA-3') (Ziętara and Lumme, 2003) were used for sequencing of the full ITS fragment. The ITS2 fragments 


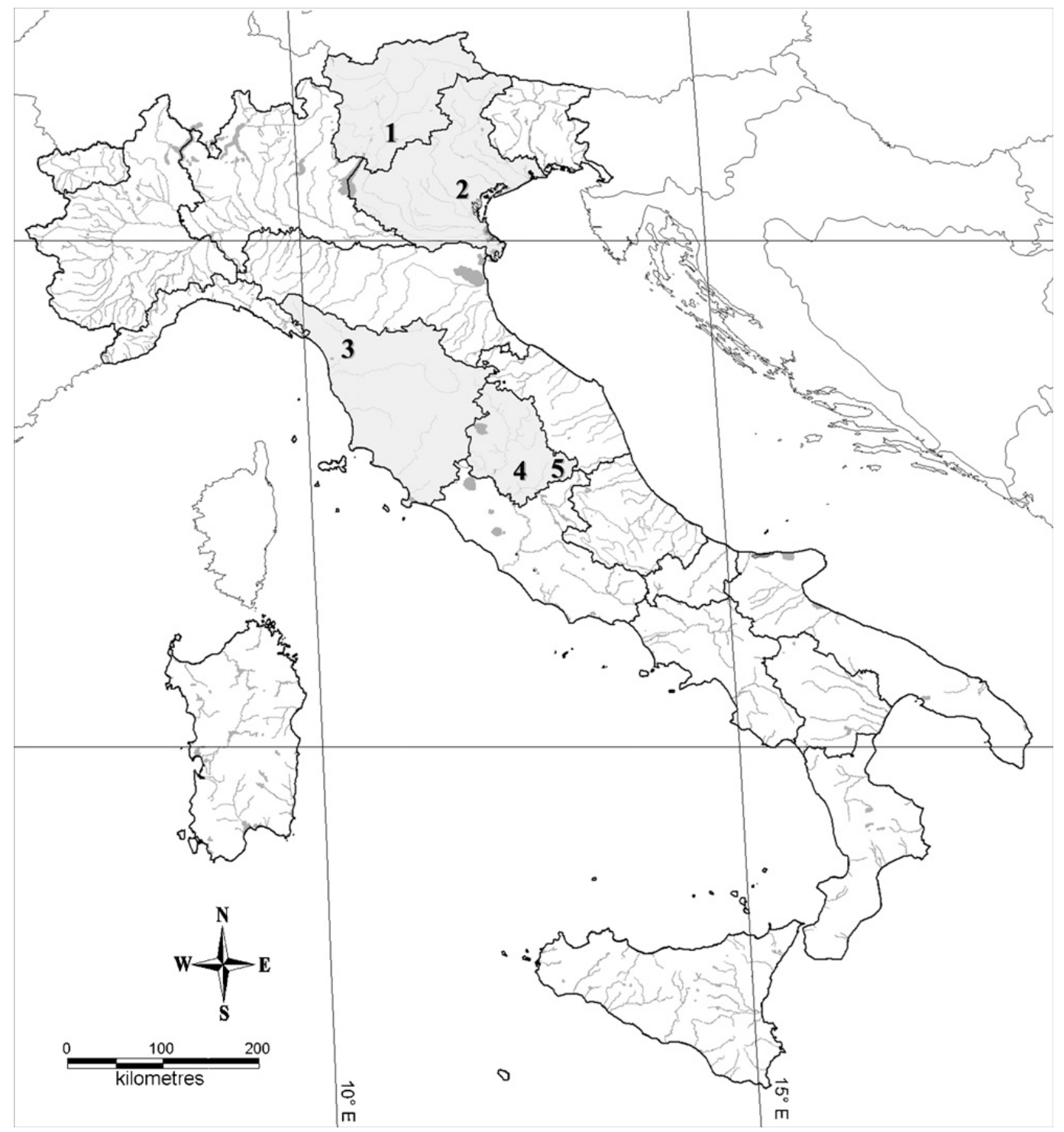

Fig. 1. The location of the rainbow trout farms sampled throughout Italy and found to be positive for Gyrodactylus von Nordmann. (1) Avisio Torrent,

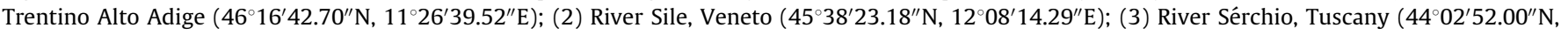
$\left.10^{\circ} 27^{\prime} 39.74^{\prime \prime} \mathrm{E}\right)$; (4) Clitunno Fountain, Umbria ( $\left.42^{\circ} 44^{\prime} 41.95^{\prime \prime} \mathrm{N}, 12^{\circ} 42^{\prime} 24.81^{\prime \prime} \mathrm{E}\right)$; (5) River Nera, Umbria $\left(42^{\circ} 51^{\prime} 41.38^{\prime \prime} \mathrm{N}, 12^{\circ} 58^{\prime} 48.84^{\prime \prime} \mathrm{E}\right)$.

were sequenced using the PCR primers only. Amplified fragments of COI were sequenced using the PCR primers in addition to ZMO2 (5'-CCAAAGAACCAAAATAAGTGTTG-3') and ZMO3 (5'-TGTCYCTACCAGTGCTAGCCGCTGG-3') (Hansen et al., 2003). Sequences were proofread in VectorNTI (Invitrogen) and identity established by submitting the sequences to a GenBank BlastN search (http:// www.ncbi.nlm.nih.gov/) (Altschul et al., 1990; Zhang et al., 2000). Calculation of genetic distances was performed in Mega 4.0 (Tamura et al., 2007).

In addition, one formalin fixed sample of Gyrodactylus was found within the fish pathology archive held by the Department of Veterinary Public Health and Animal Pathology, University of Bologna. The skin scrape, which contained five gyrodactylids, was collected in April 2000 from an unspecified rainbow trout farm within the Veneto region. The gyrodactylids were rinsed in distilled water and then prepared as whole mounts in ammonium picrate glycerine and identified by morphometry and morphology.
The sampling protocols and experimentation conducted throughout the course of the investigation complied with the laws and statutes of Italy and the diagnostic approaches required by OIE (Office International des Epizooties - World Organisation for Animal Health) for the confirmation of G. salaris (OIE, 2006).

\section{Results}

Gyrodactylids were recovered from the mucus scrapes taken from the body and the fins of the fish sampled at each of the five rainbow trout farms that were visited. All fish were found to be infected (100\%) with approximately 10 (range 5-16) gyrodactylids being recovered from each site. On the basis of morphological features taken from $\sim 10$ parasites per site $(n=53$ gyrodactylids in total), the following species were identified: Gyrodactylus derjavinoides Malmberg, Collins, Cunningham et Jalali, 2007, G. salaris, G. teuchis and G. truttae Gläser, 1974 (Table 1). Not 
Table 1

A summary of the methods used to identify the specimens of Gyrodactylus von Nordmann, 1832 collected from the five Italian rainbow trout farms visited during the current study.

\begin{tabular}{|c|c|c|c|c|}
\hline Region & G. derjavinoides & G. salaris & G. teuchis & G. truttae \\
\hline Trentino Alto Adige $(n=5)$ & - & $4 \mathrm{M} ; 1 \mathrm{ITS}^{\mathrm{a}} ; 1 \mathrm{COI}^{\mathrm{b}}$ & - & $1 \mathrm{M} ; 1 \mathrm{ITS}^{\mathrm{c}} ; 1 \mathrm{COI}^{\mathrm{c}}$ \\
\hline Tuscany $(n=16)$ & - & 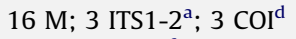 & - & - \\
\hline Umbria (R. Nera; $n=15$ ) & $3 \mathrm{M} ; 2$ ITS1-2 $; 1 \mathrm{COI}^{\mathrm{c}}$ & $2 \mathrm{M} ; 1 \mathrm{ITS} 1-2^{\mathrm{f}} ; 1 \mathrm{COI}^{\mathrm{g}}$ & $10 \mathrm{M} ; 3$ ITS1-2 $2^{\mathrm{h}} ; 1 \mathrm{COI}^{\mathrm{c}}$ & - \\
\hline Umbria (Clitunno Fountain; $n=11$ ) & $4 \mathrm{M}$ & $2 \mathrm{M}$ & $5 \mathrm{M}$ & - \\
\hline Veneto (R. Sile; $n=6$ ) & - & $6 \mathrm{M} ; 3$ ITS2 $^{\mathrm{a}} ; 2 \mathrm{COI}^{\mathrm{b}}$ & - & - \\
\hline Veneto (archive sample; $n=5$ ) & - & $5 \mathrm{M}$ & - & - \\
\hline
\end{tabular}

In addition, one Gyrodactylus positive sample collected from an unspecified rainbow trout farm dated April 2000 and deposited in the University of Bologna fish tissue archive was also examined. Each specimen was identified initially by morphology and morphometry ( $\mathrm{M}$ ) and then, where possible, confirmed by comparing the base sequence of its cytochrome oxidase 1 gene (COI) and the internal transcribed spacer 1 and 2 regions (ITS1-2) with sequences held in NCBI GenBank (http://www.ncbi.nlm.nih.gov/).

a $100 \%$ ITS identity with NCBI acc. nos. Z72477, DQ916137, DQ919059, AF484544 and AF328871.

b $100 \%$ COI identity with haplotype F from rainbow trout (Hansen et al., 2003).

c Not amplified.

d Corresponds to haplotype $\mathrm{F}$ from rainbow trout (Hansen et al., 2003).

e $100 \%$ ITS identity with NCBI acc. no. AF484530.

f $100 \%$ ITS identity with NCBI acc. nos. DQ919059 and AF328871.

g New haplotype (acc. no. GQ370816).

h $100 \%$ ITS identity with NCBI acc. no. AJ249350.

every species was found at all farms; G. salaris, however, was present on the stock at all five farms, notably Tuscany and Veneto where G. salaris was the only gyrodactylid species found. Gyrodactylus teuchis was identified from the two farm sites located in the Umbria region (Clitunno Fountain and River Nera), alongside G. salaris and $G$. derjavinoides. Gyrodactylus truttae was found in Trentino Alto Adige (Avisio Torrent) together with G. salaris. As the morphology of the attachment hooks of $G$. salaris and $G$. teuchis are similar and photographic images of the latter have not been formerly presented elsewhere, figure plates of these alongside $G$. derjavinoides and $G$. truttae are provided to assist in their future identification and discrimination (Figs. 2 and 3 ).

From Figs. 2 and 3, the four species of Gyrodactylus can be readily discriminated from each other based on the unique shape of the marginal hook sickle. As all specimens were collected in the same season (March-May 2005) and from water bodies of a similar temperature $\left(\sim 11-12.5^{\circ} \mathrm{C}\right)$, the size of the attachment hooks of the four species can be compared. Gyrodactylus salaris is the largest of the four species, the total length of the hamuli and the marginal hooks were $\sim 76 \mu \mathrm{m}$ and $\sim 39.5 \mu \mathrm{m}$ respectively compared to $\sim 68 \mu \mathrm{m}$ and $\sim 36 \mu \mathrm{m}$ for G. teuchis, $\sim 63 \mu \mathrm{m}$ and $\sim 23.5 \mu \mathrm{m}$ for G. truttae, and $55 \mu \mathrm{m}$ and $\sim 33 \mu \mathrm{m}$ for $G$. derjavinoides.

Although frequently drawn, relatively few photographic images of the male copulatory organ (MCO) exist within the literature; those of G. derjavinoides, G. salaris and $G$. teuchis are presented for the first time. Only one specimen of $G$. truttae was found in the current study but this individual was prepared for molecular analysis and therefore there was no opportunity to look at the configuration of spines on the MCO. The armature of the MCO, however, in the former three species are different from each other. The MCO of G. salaris which measures approximately $30 \mu \mathrm{m}$ in diameter, bears a single arch of 67 spines ( 2 large, terminal $\sim 6.2 \mu \mathrm{m}$ long and $4-5$ mediumsized $\sim 5.3 \mu \mathrm{m}$ long central spines). In addition, 4-6 small, circular studs ( $\sim 1.2 \mu \mathrm{m}$ in diameter), the precise structure of which have not been formally described, are observed scattered around the main arch of spines but are not in any set, discernible configuration (Fig. 2f-h). The MCO of G. teuchis, which measures $\sim 25 \mu \mathrm{m}$ in diameter, bears $4-5$ similar, large-sized spines ( $\sim 5 \mu \mathrm{m}$ long) arranged in a single arch with 1-2 visible small, circular studs (Fig. 3f and $\mathrm{g}$ ). The MCO of $\mathrm{G}$. derjavinoides measures $26 \mu \mathrm{m}$ in diameter and bears 8 spines in a single arch ( 2 mediumsized, terminal spines $\sim 4.4 \mu \mathrm{m}$ long and 6 smaller-sized $\sim 3.2 \mu \mathrm{m}$ long central spines). No circular studs were observed (Fig. 3j).

Only fourteen specimens were available for molecular characterisation by sequencing of the ITS 1 and ITS 2 or ITS2 separately (Table 1). From these samples, G. salaris, G. teuchis and $G$. derjavinoides were confirmed. Only one specimen of $G$. truttae was available for the molecular analysis and no sensible sequence reads were obtained from it. For the seven specimens identified as G. salaris by morphological analysis or by sequencing of ITS, the base sequence of their cytochrome oxidase I genes were also determined. Six of the sequences corresponded to the mitochondrial $\mathrm{F}$ haplotype that is common in rainbow trout farms across Europe (see Meinilä et al., 2004; Hansen et al., 2003, 2006, 2007) and three of these sequences contained some ambiguities that could be the result of PCR or sequencing errors. The last sequence represents a new haplotype of $G$. salaris and is submitted under GenBank accession number GQ370816. This haplotype (774 bp) differs from haplotype $\mathrm{F}$ with 11 nucleotide substitutions (K2-distance: 0.0147) and is not identical to any other currently known haplotypes. The most closely related sequences in GenBank are AY225307 and AY225308 (5 nucleotide substitutions).

\section{Discussion}

Although gyrodactylosis represents a common and economically significant parasitic disease of rainbow trout 


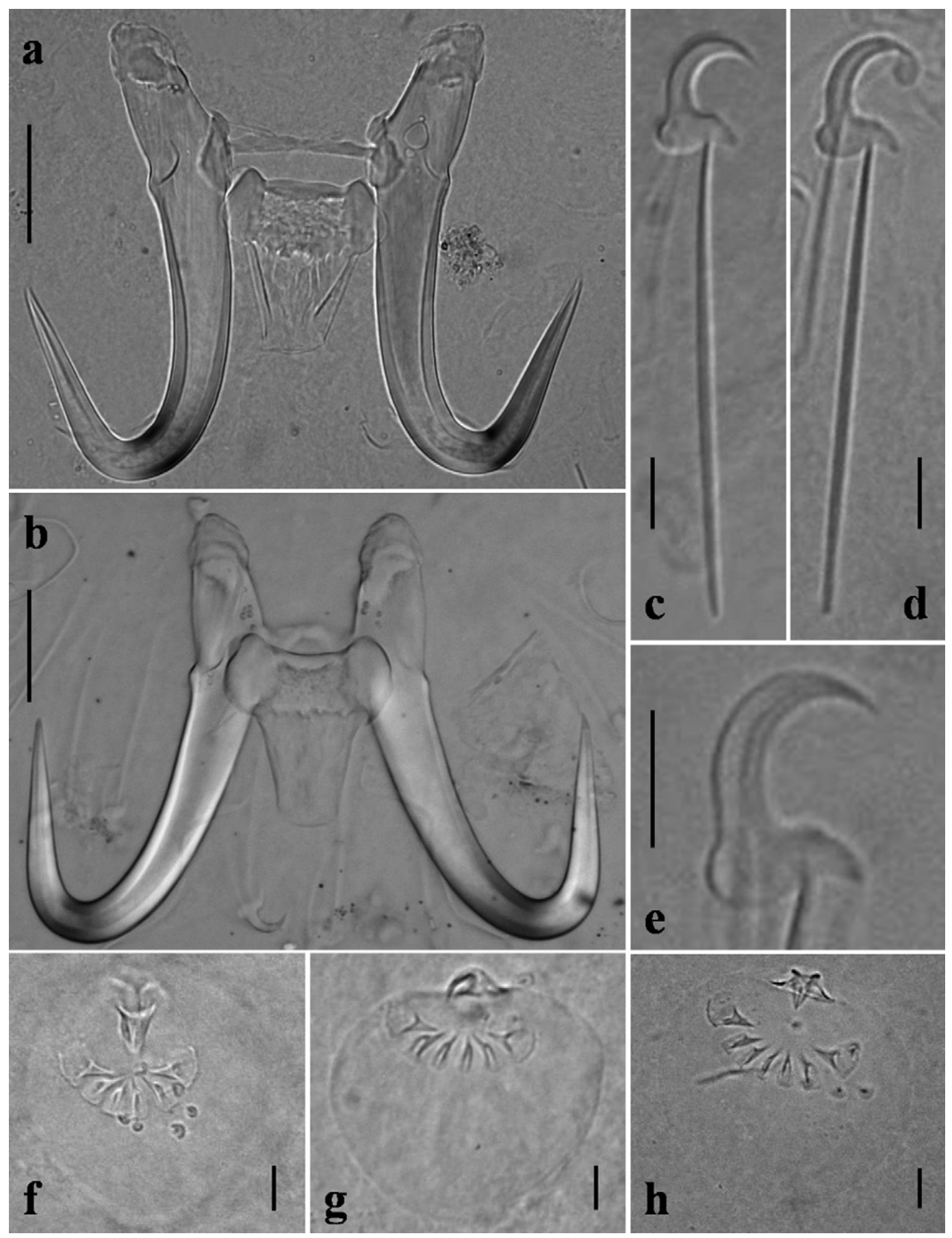

Fig. 2. Light micrographs of the haptoral hard parts and male copulatory organ of Gyrodactylus salaris Malmberg, 1957. (a and b) Central hook complex; (c-e) marginal hooks; (f-h) male copulatory organ. Scale bars, $a$ and $b=20 \mu \mathrm{m} ; \mathrm{c}-\mathrm{h}=5 \mu \mathrm{m}$.

farmed in Italy (Fioravanti and Caffara, 2007), studies aimed at identifying the Gyrodactylus species involved in its aetiology have been scarce. Molnár and Ghittino (1977) commented on the occurrence of a gyrodactylid "morphologically like G. salaris" on cultured rainbow trout and brown trout, but prior to the current study, this report was not confirmed and the figures that were presented in the earlier account do not permit a definitive identification. Gyrodactylus derjavinoides (cited as G. derjavini Mikhailov, 1975), however, is already known from Italy and has been reported from Italian brown and rainbow trout (Malmberg, 1993).
Malmberg and Malmberg (1993) suggested that $G$. salaris originated in the Baltic area; it is known to occur naturally at low intensities in this area including the Russian Onega and Ladoga water systems and within some Swedish and Finnish rivers that drain into the Baltic Sea (Ieshko et al., 1996; Shulman et al., 2000). Throughout Europe, G. salaris has also been reported from Norway (Johnsen and Jensen, 1991; Johnsen et al., 1999), from rivers on the Swedish west coast (Malmberg and Malmberg, 1993; Alenäs, 1998), Denmark (e.g. Buchmann and Bresciani, 1997; Buchmann et al., 2000), Finland (RimailaPärnänen and Wiklund, 1987; Keränen et al., 1992; Koski 

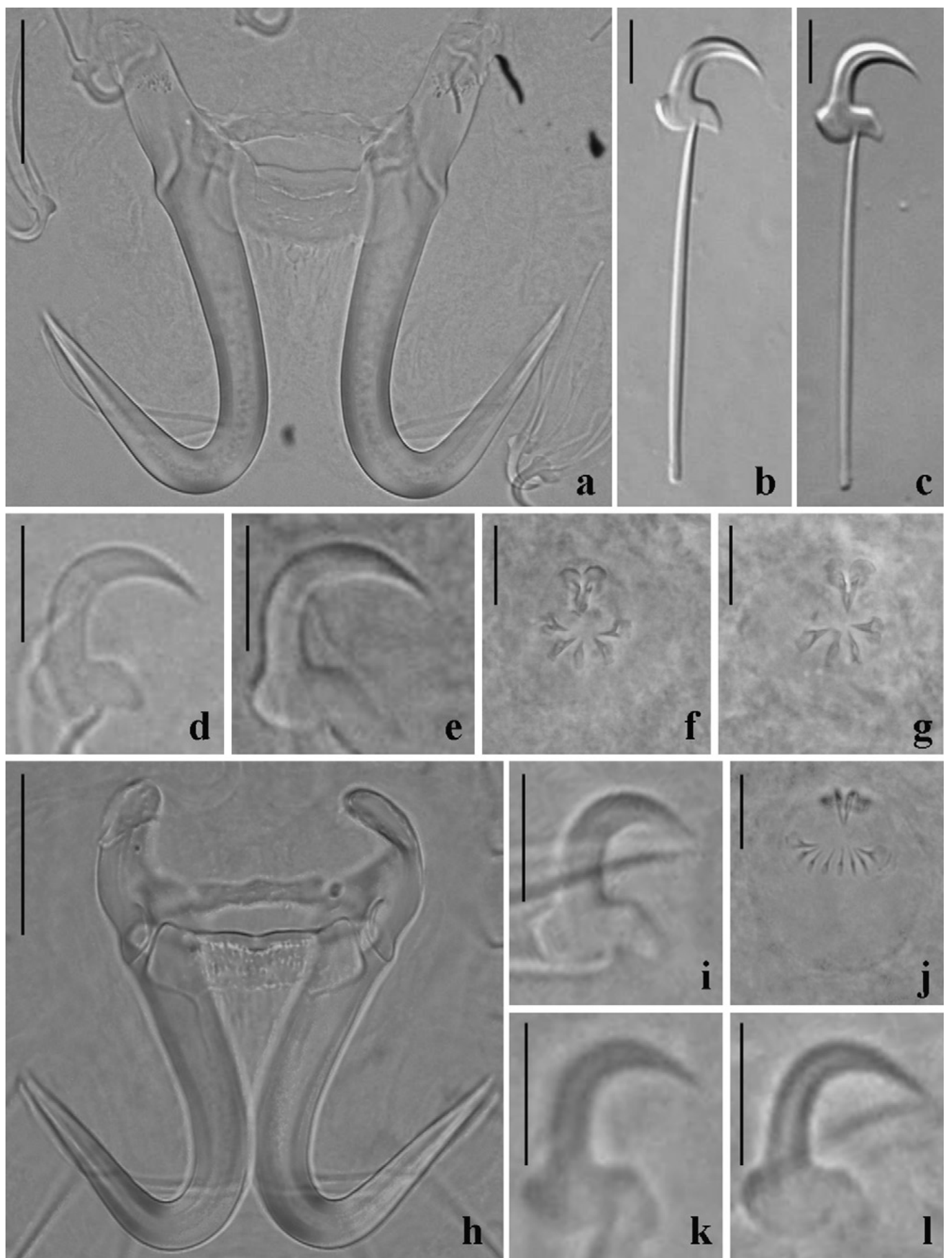

Fig. 3. Light micrographs of the haptoral hard parts of Gyrodactylus teuchis Lautraite, Blanc, Thiery, Daniel et Vigneulle, 1999 (a-g), Gyrodactylus derjavinoides Malmberg, Collins, Cunningham et Jalali, 2007 (h-j) and Gyrodactylus truttae Gläser, 1974 (k and l). Gyrodactylus teuchis: a, central hook complex; b and c, marginal hooks; d and e, marginal hook sickles; f and g, male copulatory organ; G. derjavinoides: h, central hook complex; i, marginal hook sickle; j, male copulatory organ; G. truttae: $\mathrm{k}$ and $\mathrm{l}$, marginal hook sickles. Scale bars, $\mathrm{a}, \mathrm{h}=20 \mu \mathrm{m} ; \mathrm{f}-\mathrm{g}, \mathrm{j}=10 \mu \mathrm{m} ; \mathrm{b}-\mathrm{e}, \mathrm{i}, \mathrm{k}-\mathrm{l}=5 \mu \mathrm{m}$.

and Malmberg, 1995; Koski, 1996; Rintamäki-Kinnunen and Valtonen, 1996), Russia (Ergens, 1983; Ieshko et al., 1996, 1997; Meinilä et al., 2004), Germany (Lux, 1990; Dzika et al., 2009), Spain (Malmberg, 1993), France (Johnston et al., 1996) and, most recently, from Poland (Rokicka et al., 2007). While the presence of G. salaris has been confirmed by molecular methods for many of these, the reports from certain countries, i.e. France, Spain and Portugal, awaits verification.
In addition to Atlantic salmon, G. salaris has also been recorded in the wild from other salmonids such as Arctic charr (Salvelinus alpinus L.) (see Table 2 in Bakke et al., 1992; Robertsen et al., 2007) and Adriatic trout (Salmo obtusirostris Heckel) (see Žitňan and Cankovic, 1970). Although brown trout has a limited susceptibility to G. salaris (Mo, 1988; Jansen and Bakke, 1995), it has nevertheless been reported on this host in the wild on several occasions (e.g. Mo, 1988). It is also common in many 
rainbow trout farms across Europe (Lux, 1990; Koski and Malmberg, 1995; Meinilä et al., 2004). In addition to these salmonid hosts, G. salaris has also experimentally been shown to attach and survive for a short period on some non-salmonid fish species such as the eel (Anguilla anguilla L.) and the flounder (Platichthys flesus L.) (see Mo, 1987), which may act as transport hosts (see Table 2 in Bakke et al., 1992).

The G. salaris findings from the current study, however, prompted a detailed study of preserved fish material from farm archives dating back to 2000. The formalin fixed Gyrodactylus salaris specimens were identified solely on hook morphology suggesting that this species may have been in the country for the past nine years. This latter finding has provided the impetus for a larger study of gyrodactylids on Italian salmonids which is currently underway.

Only one specimen of $G$. truttae from Trentino Alto Adige (Avisio Torrent) was found in the current study. Given the small number of fish that were sampled from each site and the sampling strategy that was used (i.e. skin scrapes), the likelihood of $G$. truttae occurring on stock held at the other farms cannot be ruled out. Gyrodactylus teuchis has previously been reported in France, sporadically in Denmark and the UK and appears to be common on rainbow trout in Polish fish farms (Lautraite et al., 1999; Cunningham et al., 2001; Rokicka et al., 2007). Lautraite et al. (1999) found $G$. teuchis to be widely distributed on both wild and farmed salmonids from Brittany to the Western Pyrénées, and the current survey now extends its distribution into Italy. In the current study, G. teuchis was found at two sites in Central Italy and, on both occasions, in association with $G$. salaris.

This study represents the first confirmed presence of $G$. salaris in Italy, which was the most commonly encountered gyrodactylid species on farmed rainbow trout and this extends the reported range of this parasite in Europe. Identification of most of the $G$. salaris specimens as haplotype $F$ (Table 1 ), which are common in rainbow trout farms, provides supporting evidence to suggest that $G$. salaris has mainly been spread via the rainbow trout trade rather than from the local indigenous fish population. The finding of a new haplotype on rainbow trout is not surprising as several haplotypes have been recovered from salmon and grayling (Hansen et al., 2003, 2006, 2007; Meinilä et al., 2004). Further investigation, however, is needed to ascertain whether this infection originates from rainbow trout introduced to the farm or from wild fish in the River Nera. This survey together with recent studies on gyrodactylids in rainbow trout farms in Europe (e.g. Rokicka et al., 2007; Dzika et al., 2009) points to the importance of this industry for spreading of $G$. salaris in Europe. It seems more than likely that the examination of rainbow trout farms in other countries will extend the range further.

\section{Acknowledgements}

The authors would like to thank Dr. Fabio Rogato for his help in providing samples for the current study. We would also like to thank the staff of all the farms visited throughout this study for their kind assistance and support. We also extend our thanks to Professor Massimo Trentini from the University of Bologna and the Degree Course in Aquaculture and Ichthyopathology, Cesenatico (FC), Italy for awarding GP a scholarship to undertake this study. The authors would also like to thank Dr. Cosimo Paladini and Dr. Sandro Pelini for their assistance in producing a map of the study area.

\section{References}

Alenäs, I., 1998. Gyrodactylus salaris på lax i svenska vattendrag och lax problematiken på svenska västkusten. Vann 1,135-142 (in Swedish).

Altschul, S.F., Gish, W., Miller, W., Myers, E.W., Lipman, D.J., 1990. Basic local alignment search tool. J. Mol. Biol. 215, 403-410.

API - Associazione Piscicoltori Italiani, 2008. Sistema di monitoraggio API Acquacoltura Italiana 2007. Acquacoltura - API Informa 23 (7/8), pp. 4-5 (in Italian).

Bakke, T.A., Harris, P.D., Jansen, P.A., Hansen, L.P., 1992. Host specificity and dispersal strategy in gyrodactylid monogeneans, with particular reference to Gyrodactylus salaris (Platyhelminthes, Monogenea). Dis. Aquat. Org. 13, 63-74.

Bakke, T.A., Harris, P.D., Cable, J., 2002. Host specificity dynamics: observations on gyrodactylid monogeneans. Int. J. Parasitol. 32, 281-308.

Bakke, T.A., Cable, J., Harris, P.D., 2007. The biology of gyrodactylid monogeneans: the "Russian-doll killers". Adv. Parasitol. 64, 161-376.

Buchmann, K., Bresciani, J., 1997. Parasitic infections in pond-reared rainbow trout Oncorhynchus mykiss in Denmark. Dis. Aquat. Org. 28, 125-138.

Buchmann, K., Lindenstrøm, T., Nielsen, M.E., Bresciani, J., 2000. Diagnostik og forekomst af ektoparasitinfeksjoner (Gyrodactylus spp.) hos danske laksefisk. Dansk Vet. Tidsskr 83 (21), 15-19 (in Danish).

Cunningham, C.O., Mo, T.A., Collins, C.M., Buchmann, K., Thiery, R., Blanc, G., Lautraite, A., 2001. Redescription of Gyrodactylus teuchis Lautraite, Blanc, Thiery, Daniel \& Vigneulle, 1999 (Monogenea: Gyrodactylidae); a species identified by ribosomal RNA sequence. Syst. Parasitol. 48, 141-150.

Dzika, E., Maciejewska, I.W., Hoffmann, R.W., Oidtmann, B., 2009. The Gyrodactylidae fauna of rainbow trout Oncorhynchus mykiss Walbaum 1792 in the Rogg breeding pound in Bavaria, Germany. Parasitol. Res. 104, 671-676.

Ergens, R., 1983. Gyrodactylus from Eurasian freshwater Salmonidae and Thymallidae. Folia Parasitol. 30, 15-26.

Fioravanti, M.L., Caffara, M., 2007. Le principali malattie parassitarie dei salmonidi allevati in Italia. In: Baruchelli, G. (Ed.), Tecniche di allevamento e trasformazione della trota. Ist. Agr. S. Michele all'Adige, Trento, Italy, pp. 327-356 (in Italian).

Hansen, H., Bachmann, L., Bakke, T.A., 2003. Mitochondrial DNA variation of Gyrodactylus spp. (Monogenea, Gyrodactylidae) populations infecting Atlantic salmon, grayling and rainbow trout in Norway and Sweden. Int. J. Parasitol. 33, 1471-1478.

Hansen, H., Martinsen, L., Bakke, T.A., Bachmann, L., 2006. The incongruence of nuclear and mitochondrial DNA variation supports conspecificity of the monogenean parasites Gyrodactylus salaris and $G$. thymalli. Parasitology 33, 639-650.

Hansen, H., Bakke, T.A., Bachmann, L., 2007. Mitochondrial haplotype diversity of Gyrodactylus thymalli (Platyhelminthes; Monogenea): extended geographic sampling in United Kingdom, Poland, and Norway reveals further lineages. Parasitol. Res. 100, 1389-1394.

Harris, P.D., Cable, J., 2000. Gyrodactylus poeciliae n. sp. and G. milleri n. sp. (Monogenea: Gyrodactylidae) from Poecilia caucana (Steindachner) from Venezuela. Syst. Parasitol. 47, 79-85.

Ieshko, E.P., Shulman, B.S., Shurov, I.L., 1996. Peculiarities of Atlantic salmon (Salmo salar L.) parasite fauna. In: Larsen, T. (Ed.), Report from Seminar on Fish Diseases and Organisation of the Fish Health Service in the Finnish, Norwegian and Russian Parts of the Barents Region. Høgskolen i Finnmark 12, 52-54.

Ieshko, E.P., Berland, B., Bristow, G.A., Shulman, B., Shurov, I.L., 1997. On some parasites of salmon parr (Salmo salar L. 1758) from rivers of the White Sea Basin.In: ICES/NASCO Symposium Report from a Symposium held at Bath, UK: Interactions between Salmon Culture and Wild Stocks of Atlantic Salmon: The Scientific and Management Issues. 18th to 22nd April 1997 pp. 66-73.

Jansen, P.A., Bakke, T.A., 1995. Susceptibility of brown trout to Gyrodactylus salaris (Monogenea) under experimental conditions. J. Fish Biol. $46,415-422$.

Johnsen, B.O., Jensen, A.J., 1991. The Gyrodactylus story in Norway. Aquaculture 98, 289-302. 
Johnsen, B.O., Møkkelgjerd, P.I., Jensen, A.J., 1999. The parasite Gyrodactylus salaris on salmon parr in Norwegian rivers, status report at the beginning of year 2000. NINA Opp. 617, 1-129 (in Norwegian with English summary).

Johnston, C., MacKenzie, K., Cunningham, C.O., Eiras, J.C., Bruno, D.W., 1996. Occurrence of Gyrodactylus salaris Malmberg, 1957 in Portugal. Bull. Eur. Ass. Fish Pat. 16, 89-91.

Keränen, A.L., Koski, P., Kulonen, K., Ek-Kommonen, C., Neuvonen, E., 1992. Occurrence of infectious diseases in fish farms in Northern Finland. Acta Vet. Scand. 33, 161-167.

Koski, P., 1996. Important parasites and diseases of freshwater and anadromous fish in Finland. In: Larsen, T. (Ed.), Report from Seminar on Fish Diseases and Organisation of the Fish Health Service in the Finnish, Norwegian and Russian Parts of the Barents Region, vol. 12. Høgskolen i Finnmark, pp. 87-89.

Koski, P., Malmberg, G., 1995. Occurrence of Gyrodactylus (Monogenea) on salmon and rainbow trout in fish farms in Northern Finland. Bull. Scand. Soc. Parasitol. 5, 76-88.

Lautraite, A., Blanc, G., Thiery, R., Daniel, P., Vigneulle, M., 1999. Gyrodactylids parasitizing salmonids in Brittany and western Pyrénées water basins: epidemiological features of infection and species composition. Bull. Fr. Pêche Piscic. 355, 305-325.

Lux, E., 1990. Gyrodactylus salaris-parasitierung von Salmoniden, ein diagnostisch-taxonomisches Problem. In: Bernoth, E.-M., Hoffmann, R. (Eds.), Tagung der Fachgruppe "Fischkrankheiten" in Verbindung mit der EAFP/-deutsche Sektion European Association of Fish Pathologists. Giessen: Deutsche Veterinärmedizinische Gesellschaft e. V, pp. 87-98 (in German with English summary).

Malmberg, G., 1970. The excretory systems and the marginal hooks as a basis for the systematics of Gyrodactylus (Trematoda, Monogenea). Ark. Zool. 23 (1), 1-235.

Malmberg, G., 1993. Gyrodactylidae and gyrodactylosis of Salmonidae. Bull. Fr. Pêche Piscic. 328, 5-46.

Malmberg, G., Malmberg, M., 1993. Species of Gyrodactylus (Platyhelminthes, Monogenea) on salmonids in Sweden. Fish. Res. 17, 59-68.

Matejusová, I., Gelnar, M., McBeath, A.J.A., Collins, C.M., Cunningham, C.O., 2001. Molecular markers for gyrodactylids (Gyrodactylidae: Monogenea) from five fish families (Teleostei). Int. J. Parasitol. 31, 738-745.

Meinilä, M., Kuusela, J., Ziętara, M.S., Lumme, J., 2004. Initial steps of speciation by geographic isolation and host switch in salmonid pathogen Gyrodactylus salaris (Monogenea: Gyrodactylidae). Int. J. Parasitol. 34, 515-526.

Mo, T.A., 1987. Taxonomiske og biologiske undersøkelser. Virksomheten i 1986 og forslag til virksomheten i 1987. Gyrodactylusundersøkelsene ved Zoologisk Museum, Universitetet i Oslo. Rapp. No. 2, 1-70 (in Norwegian).

Mo, T.A., 1988. Gyrodactylusundersøkelsene av fisk i forbindelse med rotenon-behandlingen av Skibotnelva i august 1988. Gyrodactylu- sundersøkelsene ved Zoologisk Museum, Universitetet i Oslo. Rapp. No. 5, 1-14 (in Norwegian).

Molnár, K., Ghittino, P., 1977. Some Monogenoidea in fishes from the River Po and fish farms in Italy. Riv. It. Piscic. Ittiop. 12 (4), 109-111.

OIE, 2006. Manual of diagnostic tests for aquatic animals 2006. Chapter 2.1.14. Gyrodactylosis (Gyrodactylus salaris). http://www.oie.int/eng/ normes/fmanual/A_00031.htm.

Peeler, E., Thrush, M., Paisley, L., Rodgers, C., 2006. An assessment of the risk of spreading the fish parasite Gyrodactylus salaris to uninfected territories in the European Union with the movement of live Atlantic salmon (Salmo salar) from coastal waters. Aquaculture 258, 187197.

Rimaila-Pärnänen, E., Wiklund, T., 1987. The occurrence of Gyrodactylus salaris in freshwater fish farms. Suom. Eläinläakäril. 93, 506-507 (in Finnish).

Rintamäki-Kinnunen, P., Valtonen, T., 1996. Finnish salmon resistant to Gyrodactylus salaris: a long-term study at fish farms. Int. J. Parasitol. 26, 723-732.

Robertsen, G., Hansen, H., Bachmann, L., Bakke, T.A., 2007. Arctic charr (Salvelinus alpinus) is a suitable host for Gyrodactylus salaris (Monogenea, Gyrodactylidae) in Norway. Parasitol 134, 257-267.

Rokicka, M., Lumme, J., Ziętara, M.S., 2007. Identification of Gyrodactylus ectoparasites in Polish salmonid farms by PCR-RFLP of the nuclear ITS segment of ribosomal DNA (Monogenea, Gyrodactylidae). Acta Parasitol. 52, 185-195.

Shinn, A.P., Hansen, H., Olstad, K., Bachmann, L., Bakke, T.A., 2004. The use of morphometric characters to discriminate species of laboratoryreared and wild populations of Gyrodactylus salaris and G. thymalli (Monogenea). Folia Parasitol. 51, 239-252.

Shulman, B.S., Shurov, I.L., Ieshko, E.P., 2000. Seasonal dynamics of the infestation of young landlocked salmon (Salmo salar morpha sebago Girard) by the monogenean species Gyrodactylus salaris. Parazitologiya 39, 318-321 (in Russian with English summary).

Tamura, K., Dudley, J., Nei, M., Kumar, S., 2007. MEGA4: molecular evolutionary genetics analysis (MEGA) software version 4.0. Mol. Biol. Evol. 24, 1596-1599.

Zhang, Z., Schwartz, S., Wagner, L., Miller, W., 2000. A greedy algorithm for aligning DNA sequences. J. Comput. Biol. 7, 203-214.

Ziętara, M.S., Lumme, J., 2002. Speciation by host switch and adaptive radiation in a fish parasite genus Gyrodactylus (Monogenea, Gyrodactylidae). Evolution 56, 2445-2458.

Ziętara, M.S., Lumme, J., 2003. The crossroads of molecular, typological and biological species concepts: two new species of Gyrodactylus Nordmann, 1832 (Monogenea: Gyrodactylidae). Syst. Parasitol. 55, 39-52.

Žitňan, R., Cankovic, M., 1970. Comparison of the epizootological importance of the parasites of Salmo gairdneri irideus in the two coast areas of Bosnia and Herzegovina. Helminthologia 11, 161-166. 